\title{
実験力学の諸手法と有限要素法* \\ Various Methods in Experimental Mechanics and Finite Element Method
}

\author{
河田幸 三** \\ Kozo Kawata
}

\section{1.まえがき}

TURner, Clough, Martin 招よび TOPP の米航 空学会での諭文 “Stiffness and Deflection Analysis of Complex Structures", J. Aero. Soc., 23 (1956), 805-823. 以来, 有限要素法 (Finite Element Method) の発展は著しい，構造力学，連続体力学をはじめ熱杼 よび流体力学など応用力学のあらゆる分野に新風を欦 きこんだことは明らかである ${ }^{5}$.

一方, 光弾性, 特に态力凍結法による三次元光弾 性, 光弾性皮膜法に上る実物弹塑性解析, 高速光弾性 解析；抵抗線歪み計を主体とする歪み計；モアレ法X 線法, 銅めっき法, ホログラフィーその他数々の手法 よりなる実験力学 (Experimental Mechanics) の諸分 野亦, 応力, 歪み解析はじめ, 力学的挙動の解析に 重要な役割を果たしているい

この両者の各々得意とするのはどの点か，どのよう な仕事の分担が適切であるかは最近の大変興味ある問 題といえよう. 本特集号に収載の一連の講義扰よび座 談会要旨はこの主題について諸種の角度加ら倹討を加 えようというあのである.

との方面の議論は従来む若干なされた．機械工学年 鑑（日本機械学会，1970），27 を引用してみよう， 3. 材料力学の中， 3.2.3(a) 実験的応力およびひずみ解析 （河田幸三）の項であるが，“昭和 44 年末現在，実験 力学の横綱は依然電気的ひずみ計と光弾性で, モアレ が大関に上昇, MDI 分野の Stress Wave 法は気鋭 の新入幕といえる. 注目を要する点は (1) 有限要素 法の進展で，実験力学の担当分野蛙変わるかという問 題である. 昭和 44 年秋 SESA 会長 C. E. TAYLOR (イリノイ大), A.S. KoBAYASHI (ワシントン大), 両教授，わが国の西田，大井両教授之討議した際，計 算機容量の限界によるが，実験力学の先端的な分野は たえず要求され，保守的な二次元光弾性预よび回転対 称三次元弾性のある部分牥同法で置換えられるだるう との結論に達した”と述へてある。

* 昭和 48 年 11 月 15 日原稿受理

** 東京大学宇宙航空研究所
また ARGYRIS 教授の思切った意見も紹介されてい る.（宫本博: 材料の構造解析之有限要素法, 日本航 空宇宙学会誌, 20-218 (1972/3)，130）市なわち，“む はや光弾性付有限要素法にとって代わられ，不用とな

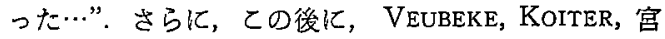
本各教授や OLLERTON 博士の“それは行過ぎではな いか. 3 次元の応力, 歪み分布を求好手段として， かつては光弾性実験が唯一の手段であったが，今や我 々は光弾性と FEM という二つの手段をすつ. そし てFEMのみによっては正解の上，下界をはさむこと ができない現在, 我々は一方によって得られた結果を 他方で確かめるのがより一層良心的であろう”という 意見が紹介されている.

筆者は, 光弾性特に応力凍結法や皮膜法弹塑性解析 (実物)，高速（または動的）光弾性解析には familiar であり，また FEM による弾塑性解析も，ここ 2 3 年のととであるが害例について当たってみた．てれら の経験をるとにして，以下若干の意見を申述べたい．

\section{2. 実験力学の諸手法の概観}

実験力学の分野は広沉でこの紙面で詳細を尽すこと はとてあできないが，各々の手法の特徽を概観してみ る.

2.1 抵抗線ひずみ計

$$
\Delta R / R=K \cdot \varepsilon
$$

$R:$ 金属線の電気抵抗, $K:$ ひずみ感度, $\varepsilon=\Delta L / L$,

$L:$ もの長さ，の関係にもとづく．特徵は，

$\circ$ point by point

○主として表面

○歪み $\varepsilon_{\theta}$

○ロゼット解析一一平面応力の解析に 3 方向の歪み を知る必要がある，ロゼット・ゲージを用いる．

。動的治強い，高周波または衝撃㱏みに対する応答
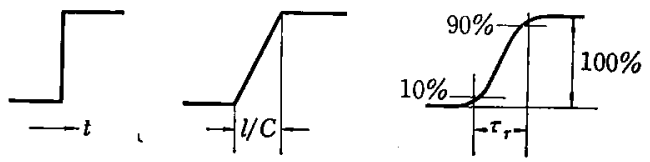

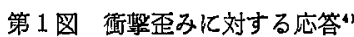


立ち上がり時間 $\tau_{r}$ (ステップ高さの $10 \%$ から 90

\%に達するに要する時間） $<0.8 l / c+0.5 \mu \mathrm{s}$

$l:$ ゲージ長, $c:$ 弾性波速度

\section{2 光弾性}

○ポリマーの光弾性効果の利用: Brewster 則

$$
\Delta n=c t\left(\sigma_{1}-\sigma_{2}\right)
$$

$\Delta n:$ 主屈折率差, $c:$ 㤂力感度, $t:$ 光路程, $\sigma_{1}-\sigma_{2}:$ 主応力差

工学的表現では,

$$
N=\alpha\left(\sigma_{1}-\sigma_{2}\right) t
$$

$N$ : 等色線次数, $\alpha$ : 光弾性感度 $(\mathrm{mm} / \mathrm{kg})$

$N, \alpha, t$ 加ら $\left(\sigma_{1}-\sigma_{2}\right)$ 名求められる.

主忍力の分析にはさらに等傾線データ $\phi$ を要する

が，自由境界では $\left(\sigma_{1}-\sigma_{2}\right)$ より直接各個の值が求めら れる。

。領域ごと, 連続的

。応力, 歪み分布の完全解析ができる.

i) 未知応力分布の解明

ii) 理論解の検定

iii) 設計, 形状の系統的変化 $\rightarrow$ 応力分布の最適化 ○分類 (口は独自の特徽を発揮するすの)

a) モデル光弾性

$N:$ 主応力差 $\left.\left(\sigma_{1}-\sigma_{2}\right)\right\}$ 主応力分析 $\phi:$ 主応力方向 $\}$ (剪断応力差穑分法)

- 2 次元光弾性, 平行光透過法- 2 次元弹性応力 分布.

静的

動的一高速光弾性

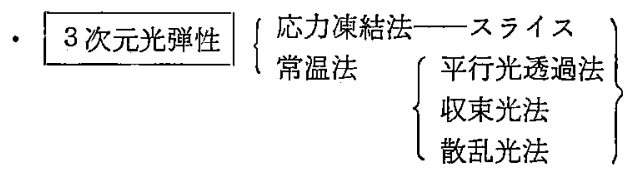

対称の有無に拘らぬ3 次元弾性応力分布

精度：ポアソン比 $\nu=0.5$ のときの值

分割 無限小まで可能 外掩

遂次削り枋とし法

b ）モデル光塑性，モデル光流性

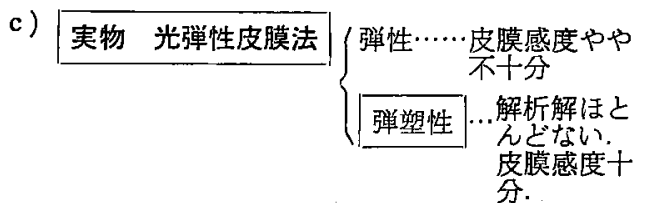

皮膜法光弾性法則（この場合は, strain-optic law)

$$
\begin{aligned}
& N=\frac{\alpha d E}{1+\mu}\left(\varepsilon_{1}{ }^{\prime}-\varepsilon_{2}{ }^{\prime}\right)=d \beta^{\prime}\left(\varepsilon_{1}{ }^{\prime}-\varepsilon_{2}{ }^{\prime}\right) \\
& d: \text { 光路程 (垂直入射なら } d=2 t, t: \text { 皮膜厚さ) }
\end{aligned}
$$

$$
\begin{aligned}
& \alpha: \text { 光弾性 (忘力) 感度 } \\
& \beta^{\prime}: \text { 主歪差感度 }=\alpha E /(1+\mu) \\
& E . \mu: \text { 皮膜のヤング係数, ポアンン比. }
\end{aligned}
$$

実物が対象で，塑性変形の微細な構造を見得る．表面 他限る。

d) 干涉計法

orthodox な光弾性というよりも，新しい領域にま たがっているというべきであるう（西田：光力学の 現状と将来性参照)

\section{3 モアレ}

○モアレ縞間隔 $\rightarrow$ 変位 $u, v$

○歪み $\varepsilon_{x}, \varepsilon_{y}, \gamma_{x y}$ を出すのに, $u, v$ の微分操作が必 要

。表面

。連続

○モデル，実物

。目下のところ，鋼の弾性歪みの解析には不満.

2.4 ひずみ塗料（ぜい性塗料，応力谽料）

。き裂方向：引張り主歪みに垂直

。き裂密度はある範囲内で歪みにほほ比例

。主応力方向之概略の応力分布を知り得る

。実物試験可, 現場

。経済的

○表面, 曲面む可

。精度 概略值

\section{$2.5 \mathrm{X}$ 線応力測定}

。標点距離として結晶の格子面間隔 $d$ を利用

○dの弾性忍力による変化をX線背面反射法により 知る.

。精度 $1 \sim 2 \mathrm{~kg} / \mathrm{mm}^{2}$ の䛊差範囲内.

○極めて局所的応力測定ができる.

\section{6 その他の方法}

\section{3. 光力学測定の精度}

- 2 次元光弾性，無限小の分割に相当.

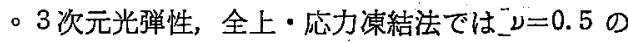
ときに該当.

。詳細はさらに, 第 2 請：西田; 光力学の現状と将 来性をむ参照されたい。

\section{FEM の精度}

。使用できる計算機の容量と分割の精度への効果に 注意.

。粗い分割では精度が急激に下がるおそれがある。

。詳細は，なかんずく第 4 講：吉村：有限要素法計 算上の問題点, 第 5 講 : 山本, 㤂力集中問題の数 值解析を参照されたい。 


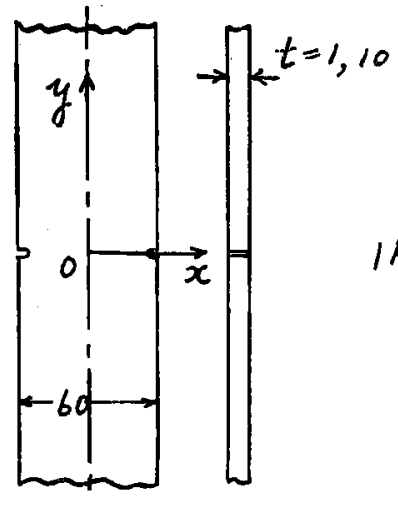

第2図試片形状

\section{5. 光弾性皮膜法実物弾塑性解析と FEM 弾塑性解析 $^{8)-10 \text { ) }}$}

両側に $R$ ノッチをもつ 2024-T3 Al 合金板材の降 伏一破壊過程研究の一環として, 塑性域拡大の模様など を，上記両手法により解析した結果の比較を行い，両 者の特徵について述べる.

5.1 切欠き板引張り降伏の光弾性皮膜法解析 材料 は 2024-T3，試片は全長 450，チャック部幅 80, 平 部長さ 200 , 同幅 60 ; 両側切欠きの㳭さ $b=5$, 曲率 行半径 $R=1$, 幅 2 ; 板厚 $t=1,10$ (第 2 図)である.

第 1 表 2024-T3 Al 板材の材料定数

\begin{tabular}{|c|c|c|c|}
\hline ヤング係数 & $\mathrm{E}$ & 7. $13_{2} \times 10^{3}$ & $\mathrm{~kg} / \mathrm{mm}^{2}$ \\
\hline ポアソン比 & $\nu$ & 0.35 & \\
\hline 降伏応力 & $Y I$ & 37.0 & $\mathrm{~kg} / \mathrm{mm}^{2}$ \\
\hline 定 数 & $a$ & 81.06 & $\mathrm{~kg} / \mathrm{mm}^{2}$ \\
\hline$"$ & $b$ & $0.5362 \times 10^{-2}$ & \\
\hline " & $n$ & 0.15 & \\
\hline
\end{tabular}

塑性域での加工硬化曲線の近似 :

$$
\sigma=a\left(b+\varepsilon_{p}\right)^{n}
$$

$\sigma$ : 応力, $\varepsilon_{p}$ : 塑性歪み, $a, b, n$ : 定数.

皮膜材料は epoxy-polysulfide $(100,100,8)$ (厚さ $2 \mathrm{~mm}$ ) で, $\beta=41 / \mathrm{mm}$, 等色線図の例を第 3 図に示 す.

\section{2 切久き板引張り降伏の FEM 数値解析}

\section{計算の概略 :}

1）降伏条件は Mises の条件，等方性.

2）塑性域での応力增分-歪み増分関係には，Prandtl Reuss の式を用いる.

3）変位関係は座標の一次関数之する.

4) 相当応力が降伏応力の $99.5 \%$ 以上に至った要 素は塑性域に入ったすのとする。

数值解析結果 : 平面応力および平面歪み条件下での 挙動を求めた，過程扰よび結果（境界条件は，対称

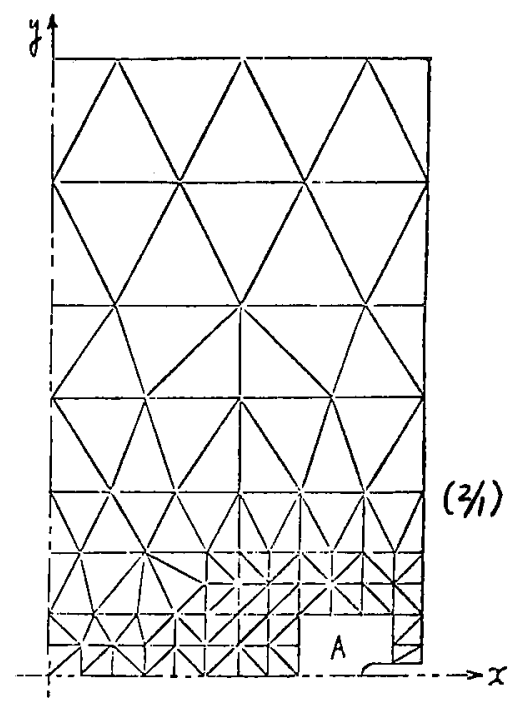

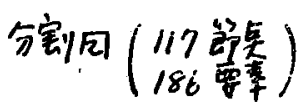

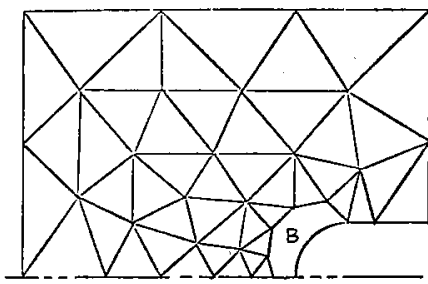

A部帝细 $(10 / 1)$

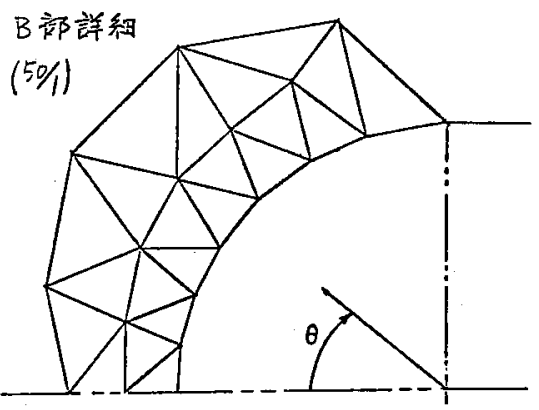

第 4 図 分割図

軸 $(x, y$ 軸) 上で変位拘束を与え，上部に一様変位を 与える）を第 4〜9 図に示す. 符 7 図は破面代表例の スケッチで FEM とは直接の関係はない，第 8,9 図 は皮膜法之の比較例である。

5.3 比較 全般的結論を下すのは，もう少し例数 を增してからの方がよいとす思われるが，本例につい て気付いた稆柄を列挙すれば次のと晾りである。

皮膜法 :

（1）表面の主歪み差分布；自由境界の主歪み，主 


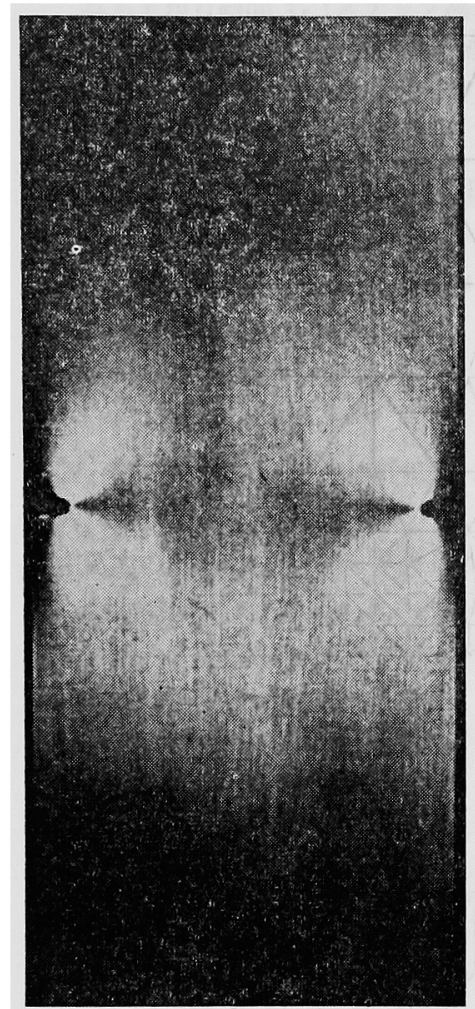

(1) $P=9$ ton

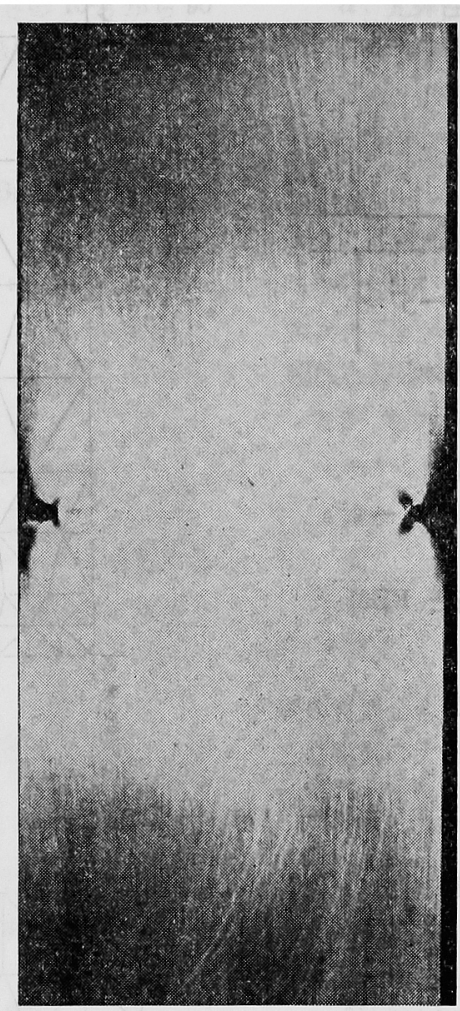

(2) $P=13$ ton

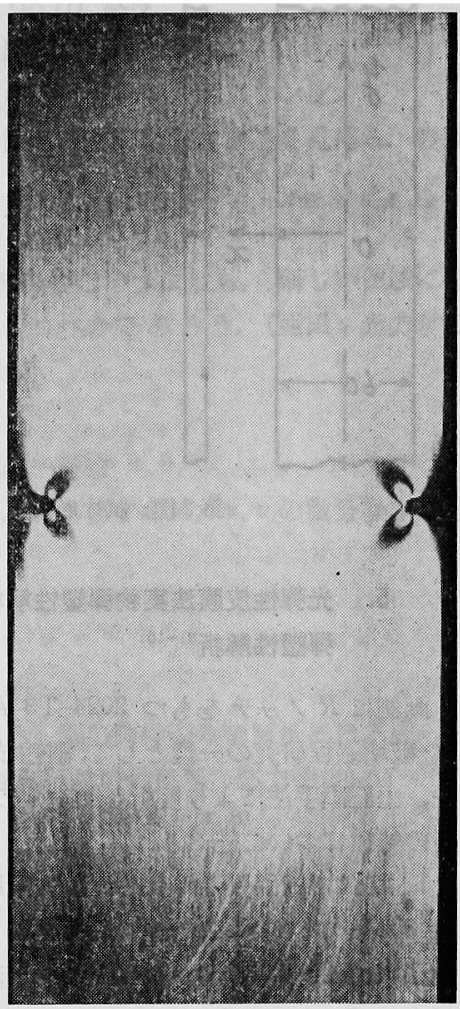

(3) $P=16$ ton

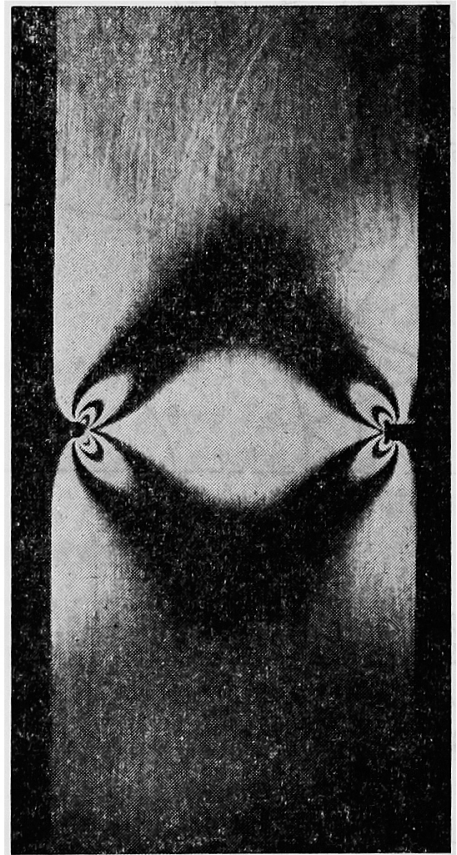

(4) $P=19$ ton

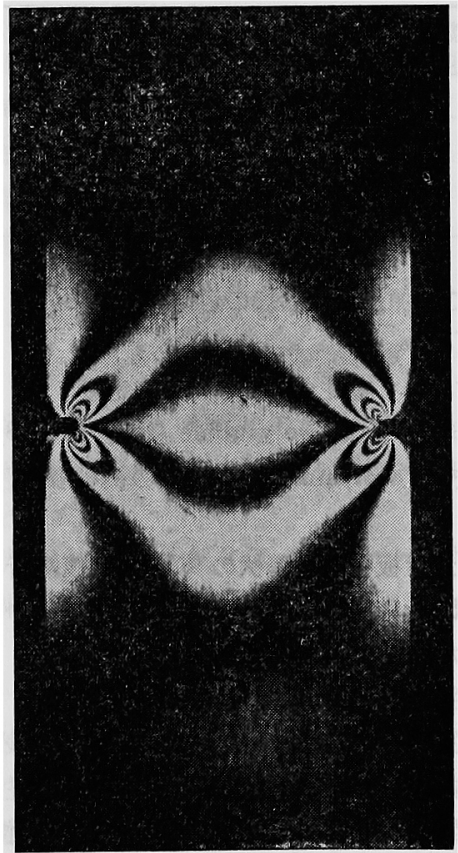

(5) $P=20$ ton

第 3 図 2024-T3 切久き板 (10 mm t) の降伏を示す皮膜法等色䌨図 


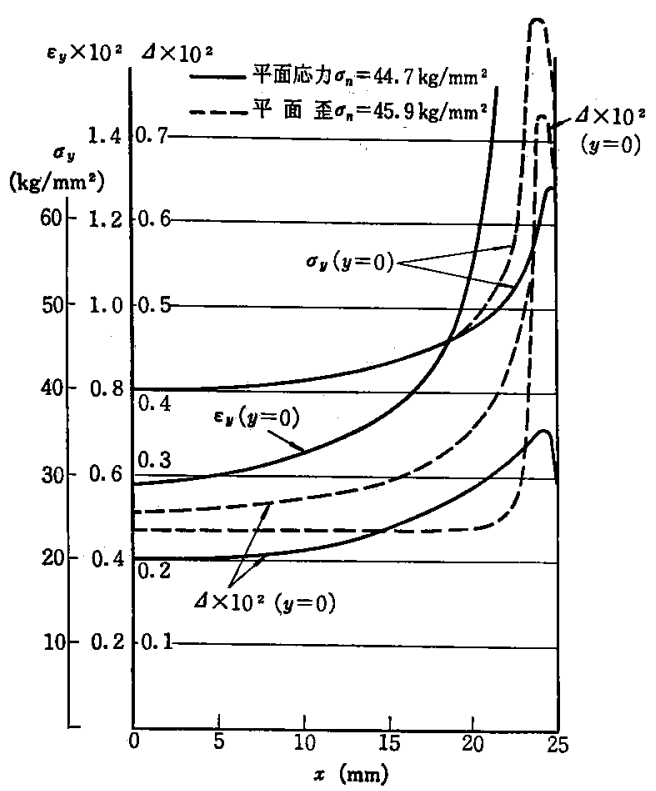

第 5 図 $y=0$ での $\sigma_{y}, \varepsilon_{y}, \Delta$ 分布の平面応力, 平面丕み 条件化よる变化

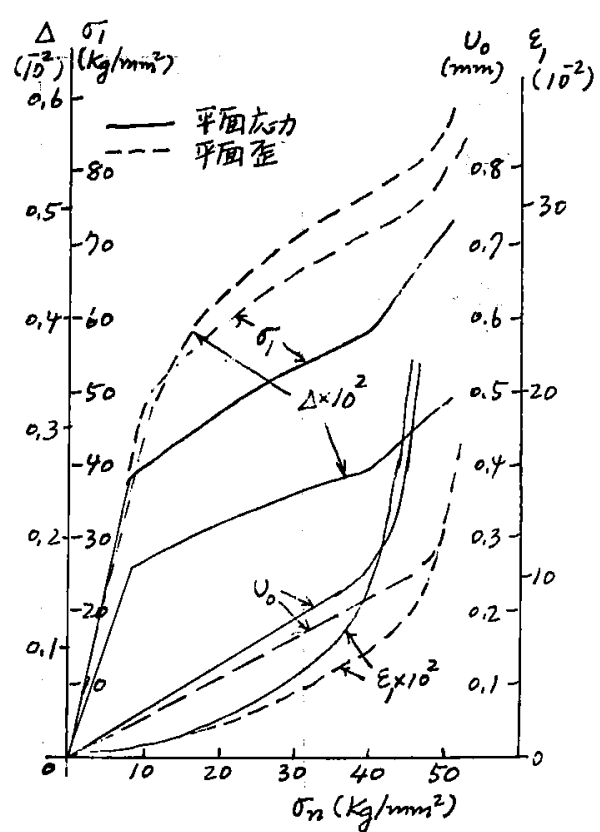

第6目 FEM で求めた $U_{0}(y=50 \mathrm{~mm}$ での変位 $), a_{1}, \varepsilon_{1}$, $\Delta(ノ ッ$ 先端での要素のそれぞれ最大主応力, 主歪み。体積膨脹) $\sigma_{n}$ (公称引張り応力) 関係.
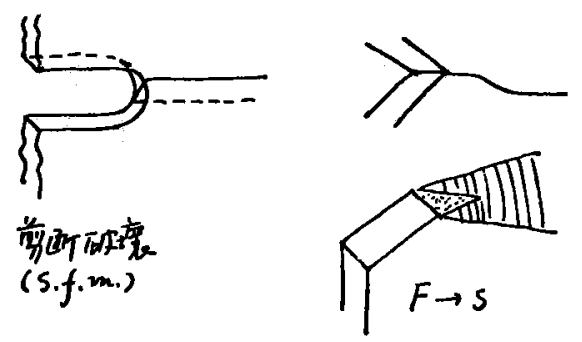

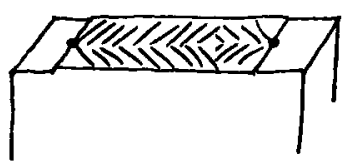

ソングギーン

(・矿境的起点)

第7図破面代表例のスケッチ

太力各個の值は，皮膜法の結果のみから容易得られ る. (KawATA (1958), Simple method) ${ }^{6)}$.

(2) 内部の主歪み,主応力の分析には, 等傾線のほ が，伝導綎法などの併用を必要とする (THEOCARIS (1963), 河田ら (1968)).

（3）複雑な形状の実構造要素について，降伏の発 生個所および流れ限度を, 容易かつ迅速に, 捕捉し得 る. 降伏発生個所が複数で, その逐次発生してくる経 過をす全く同様に, 容易に知り得る。（例は 6 亿詳細 に示すので参照されたい.)

（4）降伏の微細な構造を捕㧿し得る。

\section{FEM :}

計算に用いた構成方程式を前提として，

（1）内部の主歪み，主応力分析が一連の計算によ
り行なわれ，特に， dilatation $\Delta$ の分析などす楽にで きる:（第 5, 6 図）

（2）計算機容量の制限により，分割に制限が生じ る. 分割が粗くなると，応力集中位置で急激に精度が 低下守る惧れがある。

（3）対象の形状は比較的単独で，集中的に 1 加所 を詳しく分析するのが有利である.

（4）塑性域進展の模様は，2024-T $3 \mathrm{Al}$ 合金板材 に抢いては，大勢において，実測と一致する。

\section{6. 光弾性皮膜法による実物弾塑性解析とその若 干例 ${ }^{677}$}

光弾性皮膜法による実物弾塑性解析については，上 述以外に多くの仕事が行われているので，紹介する. 

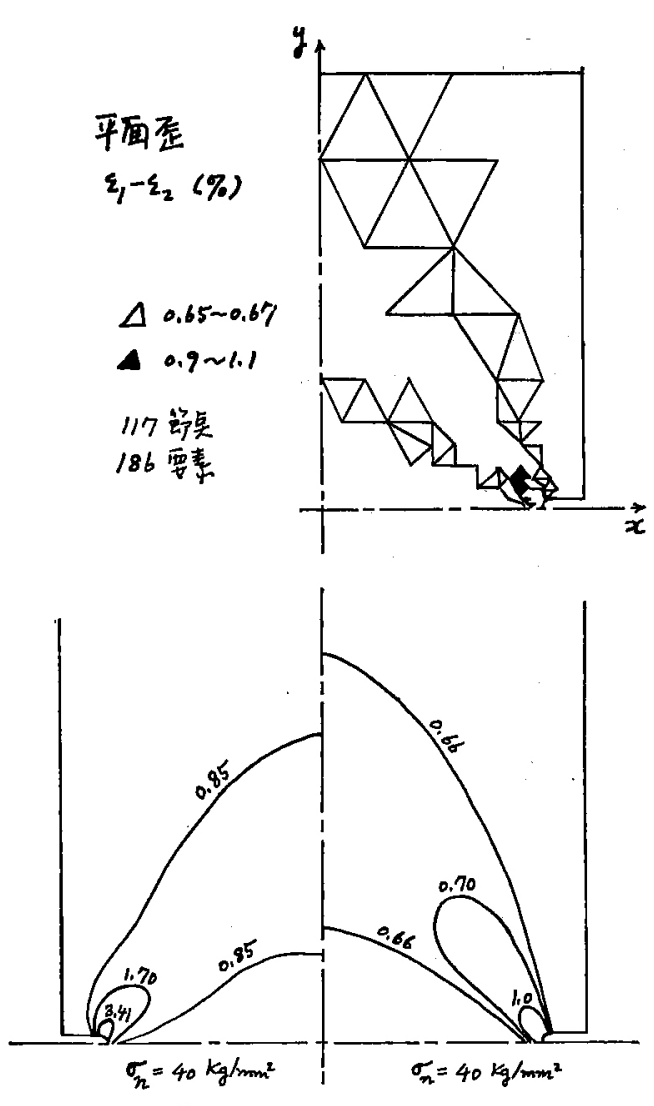

师慔法

FEM

符 8 図 2024-T3 切欠き板の降伏での主歪み益分析例 (平面丕)

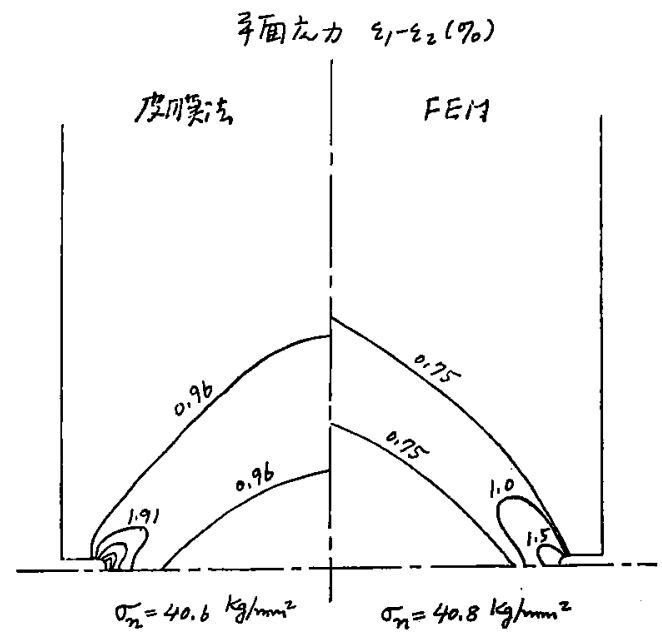

第 9 图 2024-T 3 切欠き板の降伏での主丕み差分析例 (平面応力)

この方法が最も得手とする所は, 鍋等金属構造要素の 拘束された塑性変形の領域，すなわち，応力集中個所 での局部的降伏開始より流れ限度に至る過程での自由
第 2 表 $\mathrm{R} / ッ$ 手による弾性灾力集中係数の参考值

\begin{tabular}{|c|c|c|c|c|c|}
\hline 切 欠 き & \multicolumn{4}{|c|}{$\mathrm{R}$} & $\mathrm{V}$ \\
\hline 深さ (mm) & 2.5 & 5.0 & 10.0 & 20.0 & 5.0 \\
\hline 燀性應吕 & 4.06 & 5.05 & 5.71 & 4.64 & 13.56 \\
\hline
\end{tabular}

有限要患法による分割の粗さによる誤差を含む。 基準応力は最小断面の平均応力

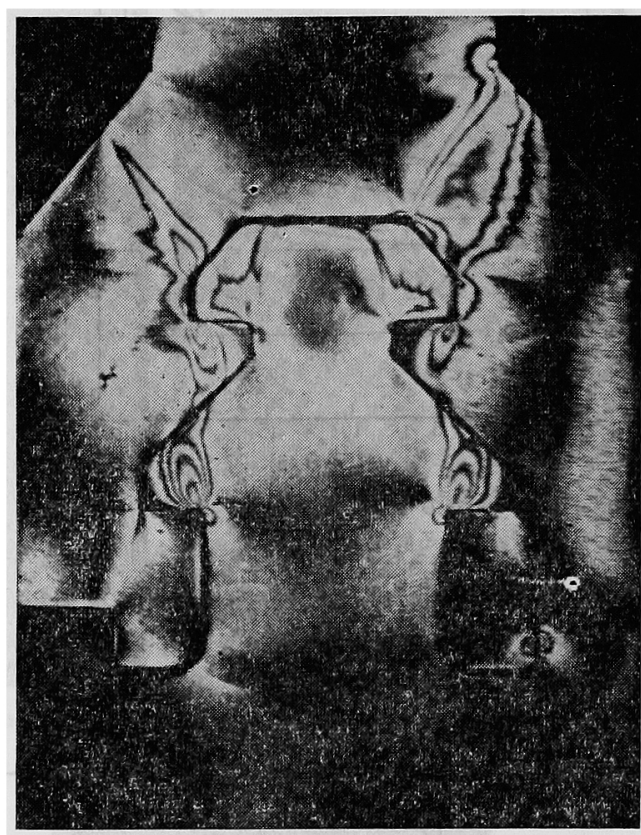

第 10 图 タービン翼根部 SF-50 鎆紫試片での逐次降伏の 発生進行する状況を示す皮膜法等色線図

境界応力, 歪み分布; 応力集中係数 平均引張り応力 (公称応力），集中個所の䄳み〜平均引張り忘力の両関 係上りの $P_{Y 0}, P_{Y}$ の決定などで，第 10 図は，後述す るタービン翼根部 SF-50 鋼製試片で逐次降伏が進行 し，巨視的な滑りが 8 か所に生じているときの皮膜法 等色線図である.

この方法は第 11, 12 図の軟鋼，Al 合金の上うに塑 性を示す材料の表面に構成された光弾性皮膜に生ずる 等色線次数 $N$ と下地表面の主歪み差 $\left(\varepsilon_{1}-\varepsilon_{2}\right)$ との直 線関係(第 11 図では単軸引張りでの $\varepsilon$ で示している) を用いるすのである(前出の皮膜法光弾性法則参照).

6.1 基本的形状試片の降状 光弾性皮膜に得られ る等色線の数例を第 13 図に示す，第 14 図は負荷の増 大化伴い，局部的降伏より塑性域貫通を経て破塄に至 る過程の等色線図の例である、第 15 図は円孔をもつ Al 合金帯板の引張りでの自由境界での境界に平行方 向の弾塑性垔み扰よび応力分布を示す.第16 図は円れ をむつ帯板の引張りでの弾塑性忍力集中係数 $\sigma / \sigma_{0}$ の 


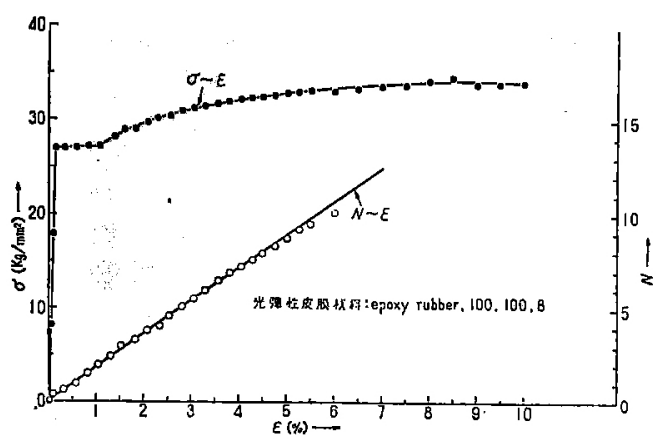

第 11 図軟鋼の單軸引張りでの応力 $\sigma$ 歪 $\varepsilon$ 関係および 光弾性皮膜の等色線次数 $N$-㳄鋼歪 $\varepsilon$ 関係

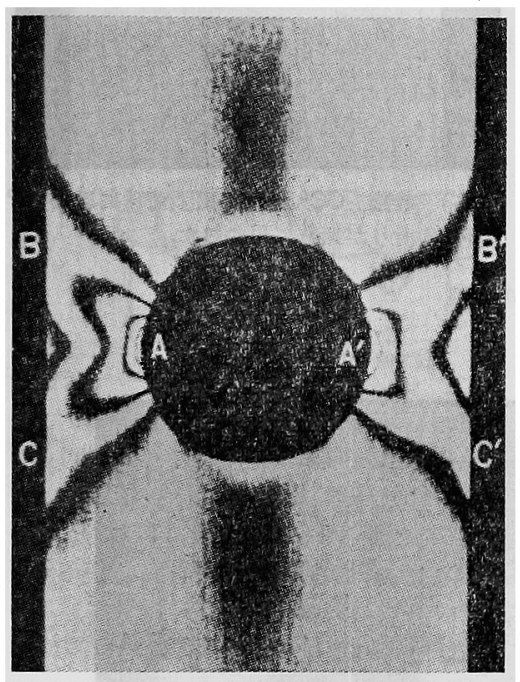

(1) Al 円孔の側壁 $A ， A^{\prime}$ よりそれぞれ ほ果 $45^{\circ}$ 上方括よひ不方の B，C; $\mathrm{B}^{\prime}, \mathrm{C}^{\prime}$ に 向け，急激に等色線の発達したのを示す。 これは降伏領域の外側壁への貫通を示す。

公称応力 $\sigma_{0}$ による変化を示す. $\sigma$ は孔の側壁での最 大応力, $\sigma_{0}$ は最狭部断面での平均引張り忍力である. 図中の矢印は局部的降伏開始点である，局部的降伏開 始後，降伏の進行につれ $\sigma / \sigma_{0}$ の低下する挙動は軟鎬 と $\mathrm{Al}$ 合金とで異なる.とれは塑性域での応力一歪み関 係の差異にあとつくものであろう.第 17 図は円孔をる つ軟鋼带板の引張りでの荷重 $P \sim$ 円側壁の応力集中 個所での自由境界平行方向の最大主歪み， $\varepsilon$ 関係で，そ の屈曲点加ら流れ限度 $P_{Y 0}$ を求め得る. 第 18 図は上 述の二つのタイプのプロットをまとめたすので，それ ぞれ $\sigma / \sigma_{0} \sim \sigma_{0}$ が弾性限度の, E〜 $\sigma_{0}$ が流れ限度の決 定に適しているてとが知られる，第 3 表にそれぞれ中 央円孔，両側 $90^{\circ}$ 切欠き，両側半円切欠きをるつ帯板 (最狭部断面皘は一㥞幅部の $1 / 2$ ) の引張りでの $P_{Y 0}$, $P_{Y}$ 等を求めた結果を示す. 表中, 弾性設計荷重, 塑

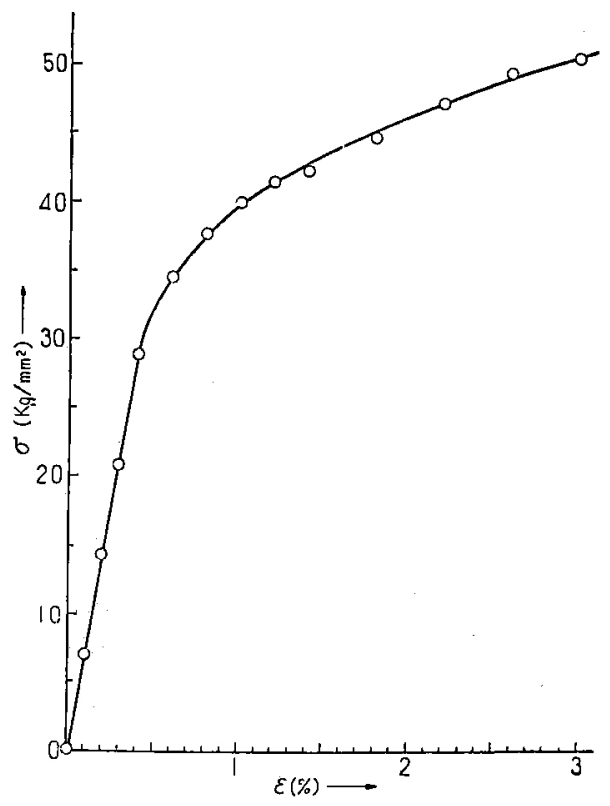

第 12 図 アルミ合金の引張応力-歪関係（曲げの実測值 から Herbert の公式により導いたあの)

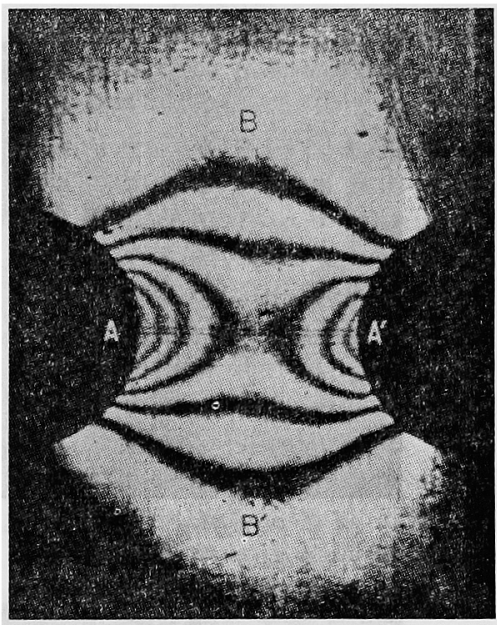

（2）㳄鍓 半円切欠の底 $\mathrm{A}, \mathrm{A}^{\prime}$ 上り水平 に内部に向け降伏領域は既に貫通している. 乙の荷重で B， $B^{\prime}$ 附近に引張り荷重に $45^{\circ}$ 方向の滑りが無数に現われた.

性設計荷重亡あるのは，それぞれ弾性限度（局部的降 伏開始荷重: $\left.P_{Y 0}\right)$, 流れ限度（塑性領域貫通時荷重： $\left.P_{Y}\right)$ である. $P_{Y} / P_{Y 0}$ が 1.7〜2.5 程度のかなり大き い值をとり，しかも材料の軟鋼と Al 合金により異な るととは注意すべきである。

6.2 複雑な形状で多重降伏のおこる場合の弾塑性 解析 ${ }^{7)}$ 次汇複䧴な形状の SF-50 鋼製タービン翼根 部試片（第 19〜21 図）弾塑性解析について述へる. 


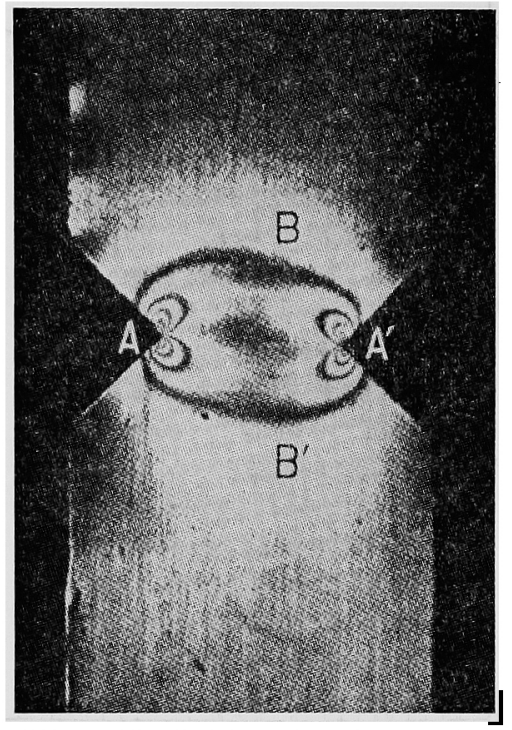

（3）軟鋼 $90^{\circ}$ 切欠の底 $\mathrm{A}, \mathrm{A}^{\prime}$ より $\mathrm{B}, \mathrm{B}^{\prime}$ 江向け等色線が既に貫通したあとを示す.

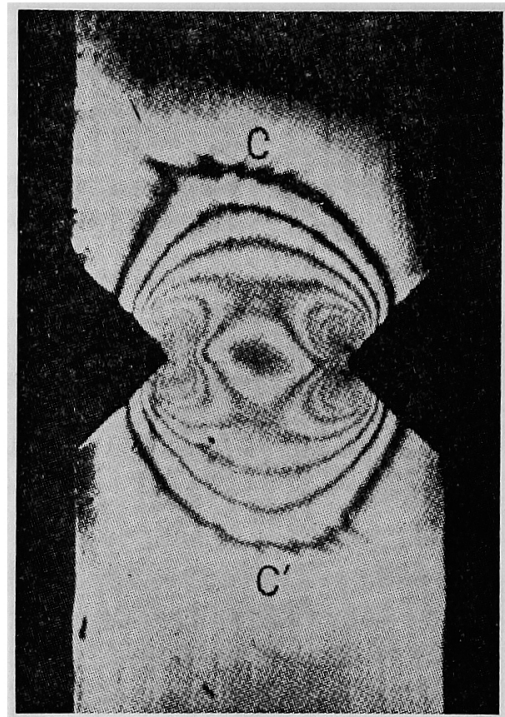

（4）㳄鎆 $\mathrm{CC}^{\prime}$ 付近に引張荷重にほ名 $45^{\circ}$ 方向の滑りが無数に現われた.

第 13 図 二三の等色線図の詳細

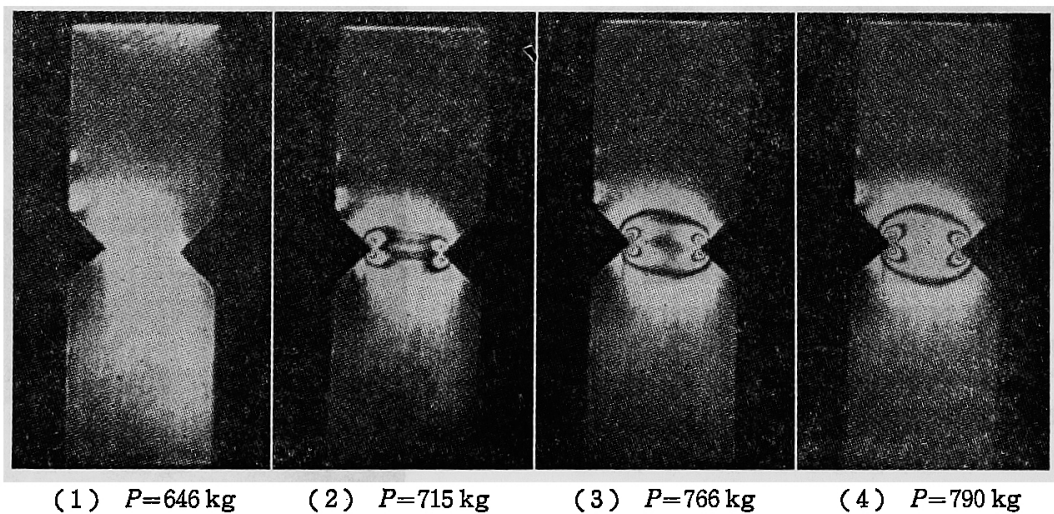

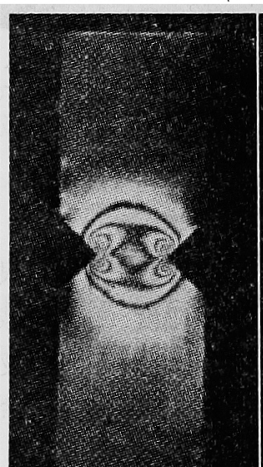

(5) $P=860 \mathrm{~kg}$

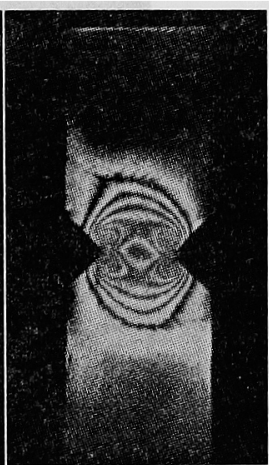

(6) $P=950 \mathrm{~kg}$

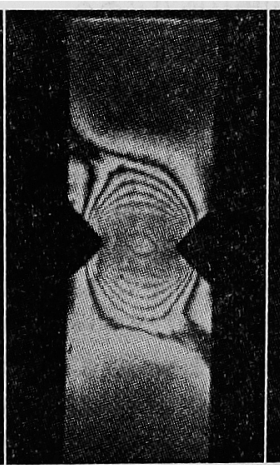

(7) $P=1014 \mathrm{~kg}$

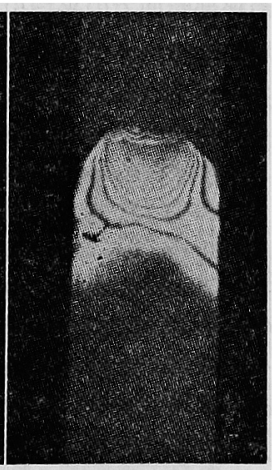

(8) 破断後

第 14 图 $90^{\circ}$ 切久を持つ㳄鋁帯板の引張りでの光弾性皮膜の等色線図 

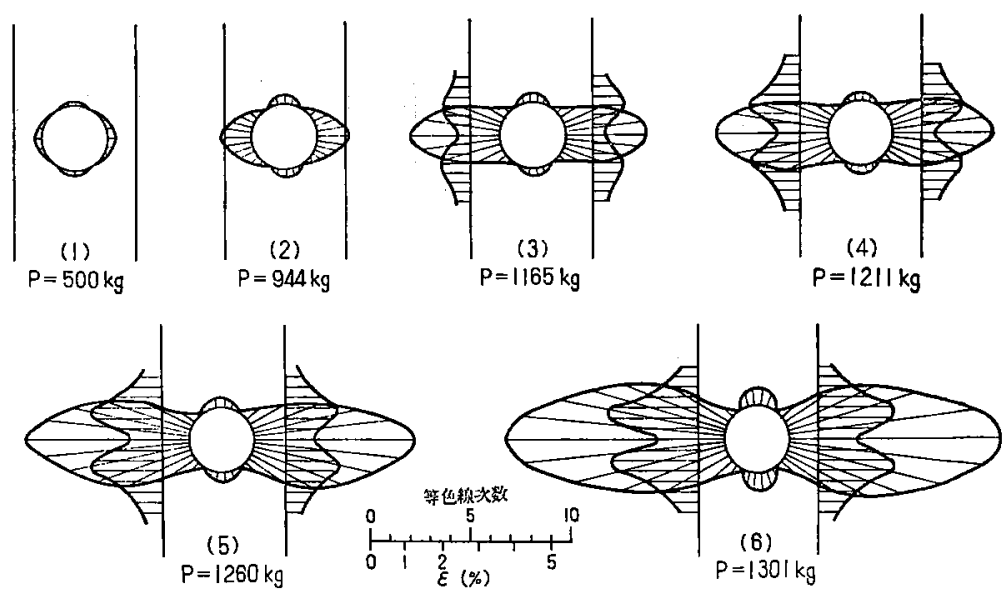

円孔を持つアルミ合金帯板の引張りでの自由境界歪み分有
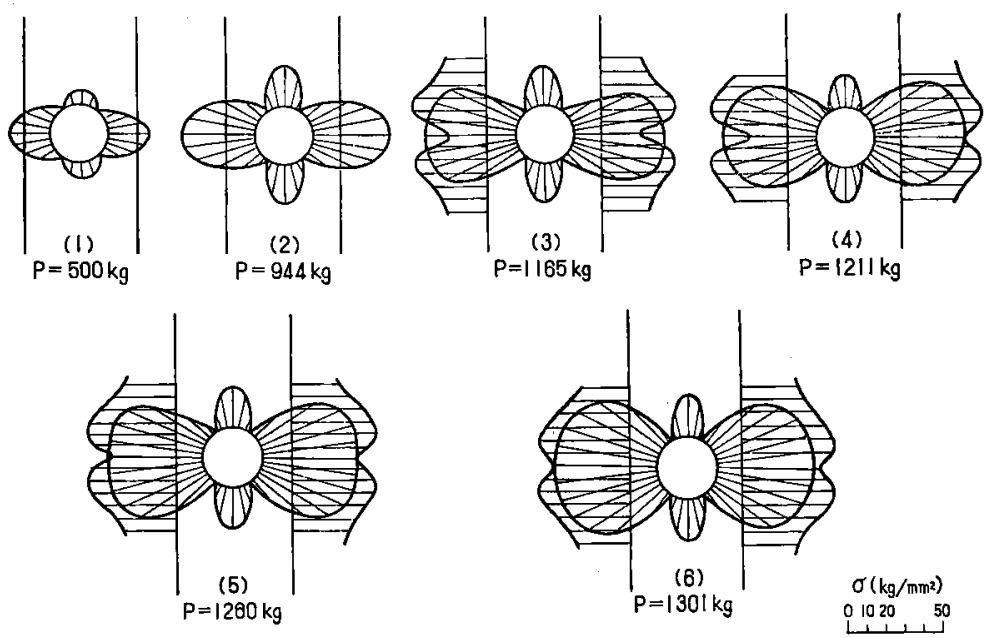

第 15 図上の歪み分布に対応する自由境界応力分在

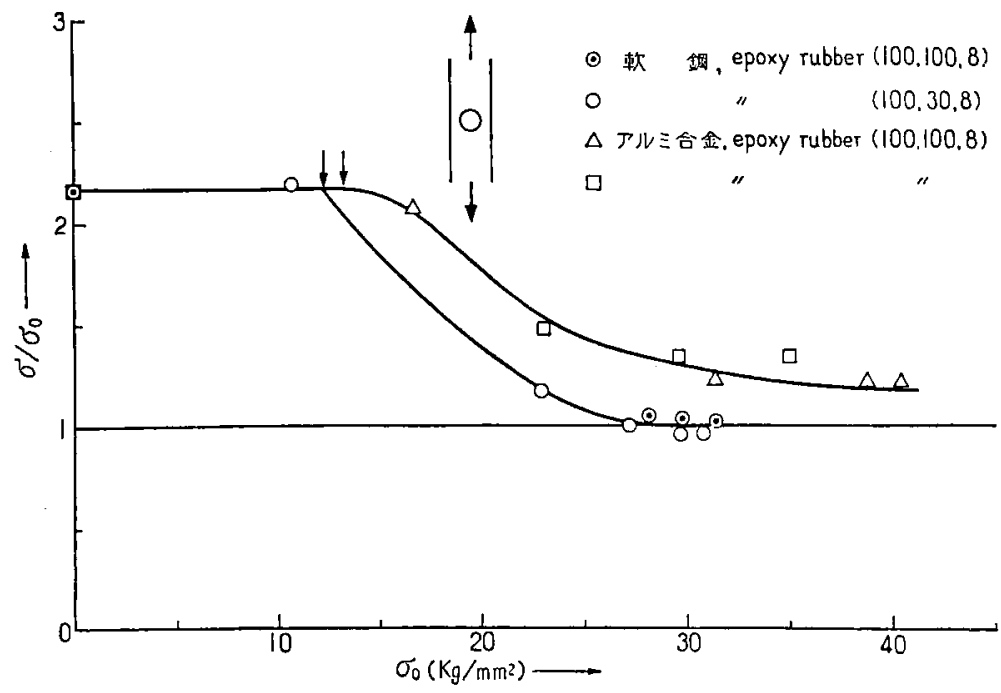

第 16 図 円孔を持つ帯板の引㖘りでの强望性応力集中係数 


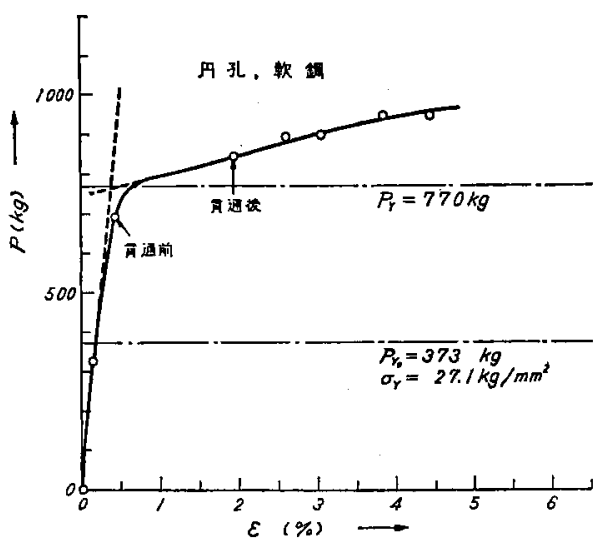

第 17 図 円孔を持つ㳄鋼帯板の引張りでの荷電-主歪み線図

この種の鋼製継手では，肩の部分で第 22 図のような 降伏の様式方共通して見られるので，模式化して示し た. このような複雑な形状の物体の降伏では，最初起 こる第一降伏域，続いて起こる別の個所での第二降伏 域，以下同様，‥という逐次降伏の発生が見られる。 代表例を第 23 図に示す．第 24 図は試験片内の主要点 の番号で，多くの領域で逐次降伏の発生する場合の表 示の便宜のためである（たとえば，第 26 図の $\sigma$ の添 字拈よび第 27 図の曲線の添字として利用). 第 25 四 はD型試片での塑性域進展図である，第 26 困は同試 片での各点の弾塑性応力集中係数の変化，第 27 図は 同試片での各点での荷重一主歪み線困を示す，第 4 表 は試片Dの数個の個所での逐次降伏の状況の記録で， $P_{Y 0}, P_{Y}$ が求められている. 第 5 表は上述の手法で求 ぬた B, C, D 各型試片での $P_{Y 0}, P_{Y}$ を示す. ての場 合, $P_{Y} / P_{Y O}$ が 3.4〜4.6の範囲で極めて高く， $P_{Y O}$ と
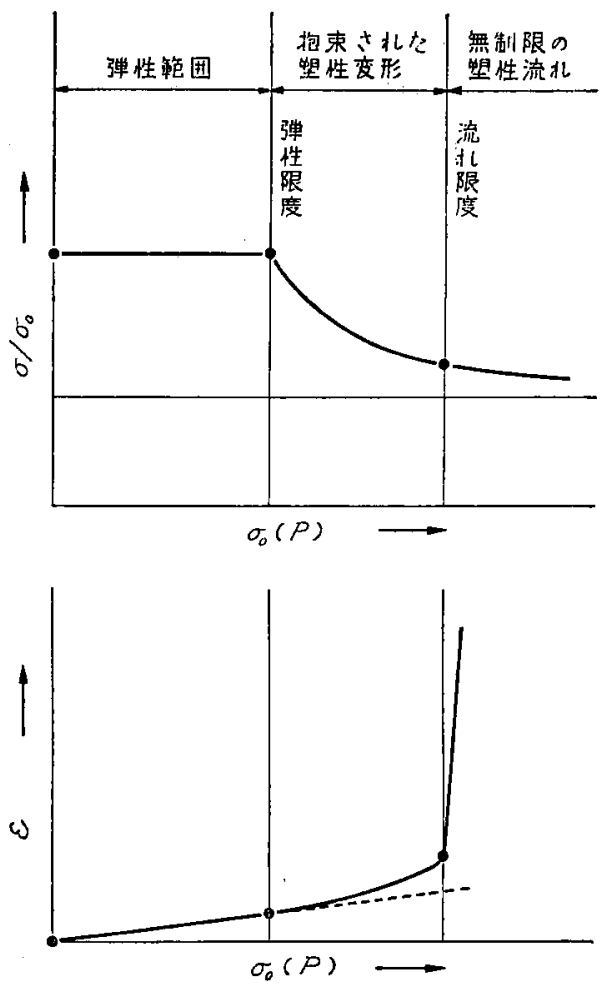

第 18 図 応力集中係数 $\sigma / \sigma_{0}$ および最大応力集中䇢 所の主歪 $\varepsilon$ の基準応力 $\sigma_{0}$ または荷重 $P$ による変化状況の概括.

$P_{Y}$ の間の荷重を有効に生かして使うことの必要さを 示唆している.

\section{7. 高速光弾性解析}

弾性波伝播による動的応力の高速光弾性解析委重要 な分野である.ここでは切久き試片の引張りでの動的

第 3表 基本的形状の切欠を持つ帯板の引張り（平面応力）での，㮖造要素としての弾性および塑性設計荷重

\begin{tabular}{|c|c|c|c|c|c|c|c|c|c|}
\hline \multirow{2}{*}{ 切 } & \multirow{2}{*}{ 欠 } & \multicolumn{4}{|c|}{ 軟鍴 $\left(\sigma_{Y}=27.1 \mathrm{~kg} / \mathrm{mm}^{2}\right)$} & \multicolumn{4}{|c|}{ アルミ合金 $\left(\sigma_{Y} \cong 30 \mathrm{~kg} / \mathrm{mm}^{2}\right) \ddagger$} \\
\hline & & $P_{Y_{0}}(\mathrm{~kg})$ & $P_{\mathbf{Y}}(\mathrm{kg})$ & $P_{Y} / P_{Y_{0}}$ & 拘束係数 & $P_{Y_{0}}(\mathrm{~kg})$ & $P_{Y}(\mathrm{~kg})$ & $P_{Y} / P_{Y_{0}}$ & 拘束你数 \\
\hline 円 & 孔 & 373 & 770 & 2. 06 & 0.95 & 413 & $985 \sim 1040$ & 2. 39 2. 52 & 1. $10 \sim 1.16$ \\
\hline $90^{\circ}$ 切 & 欠 & 361 & 620 & 1.72 & $0.76^{*}$ & 400 & - & - & - \\
\hline 半 円 切 & 欠 & 611 & 1055 & 1.73 & $1.30 \dagger$ & 677 & 1200 & 1. 77 & 1. 33 \\
\hline
\end{tabular}

ただし， $\sigma_{Y}:$ 材料の引張り降优応力, $P_{Y_{0}}:$ 弹性設計荷重, $P_{Y}:$ 塑性設計荷重 $\mathrm{P}_{Y_{0}}=\sigma_{Y} S_{0} / f$.

ただし， $f:$ 最大応力集中個所の弹性応力集中係数 (基準応力は曼狭断面での平均応力 $\sigma_{0}$ )ई， $S_{0}:$ 最狭断面の断面積,

* 参考のため，平面歪みの弾塑性問題としての数値計算結果 (Southwell \& Allen) を定性的であるにすぎないが一応挙げ ると, 1.28 .

$\dagger$ 同上, 1.22 .

$\ddagger \sigma_{Y}$ の値として, 特化応力-昰み線図汃直線から外れる際の応力をとった. 惯例のように $0.2 \%$ 永久歪みをとれば $35 \mathrm{~kg} / \mathrm{mm}^{2}$ 程度となる。

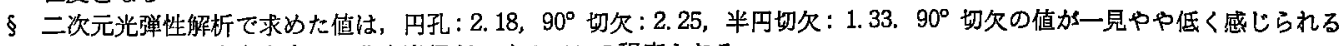
が，切久底には头際上小さい曲率半径がつくのでとの程度となる。 


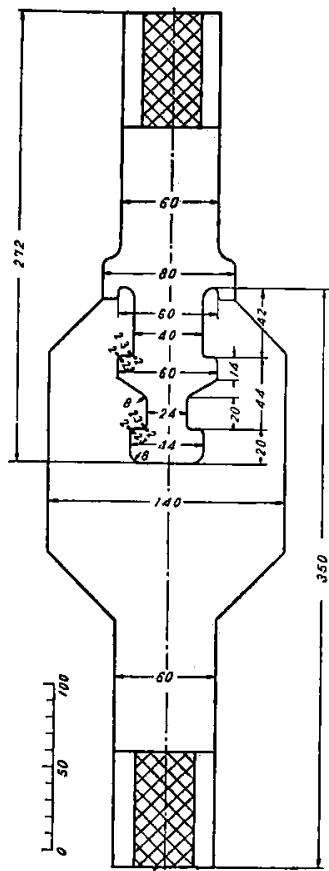

第 19 図鋼製試験片 B
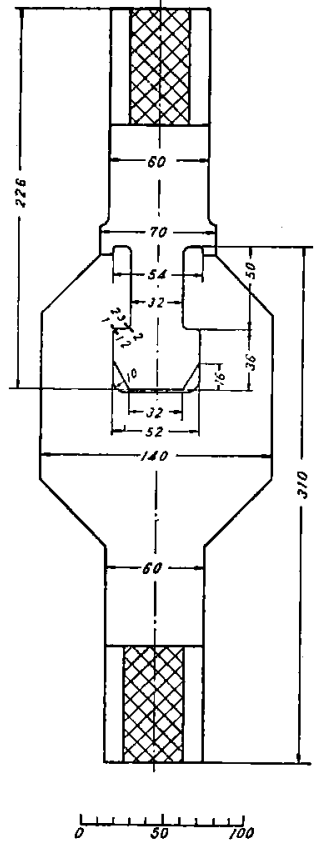

第 20 図 鋼製試験片 C
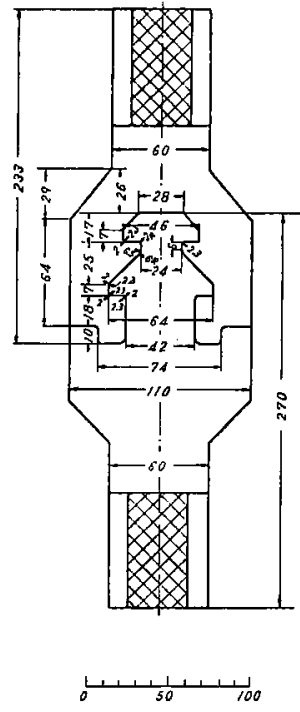

第21図鋼掣試験片 D

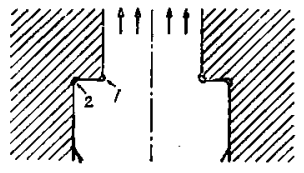

（1） 1 ，2 での局部的降伏

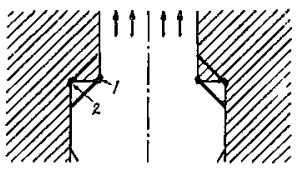

（2） 1,2より. 荷重にほ ほ $45^{\circ}$ の方向に巨視 的な滑り帯が生じ貫 通する

第 22 図 試験片Cの肩の部分の降伏の様式

第 4 表 試驗片 D 特定点の降伏状況

武験片厚さ $\left\{\right.$ ローター: $14.8 \mathrm{~mm} \quad S_{0}=60 \times 14.9=894 \mathrm{~mm}^{2}$ フレート: $14.9 \mathrm{~mm} \quad \sigma_{Y}=32.8 \mathrm{~kg} / \mathrm{mm}^{2}$

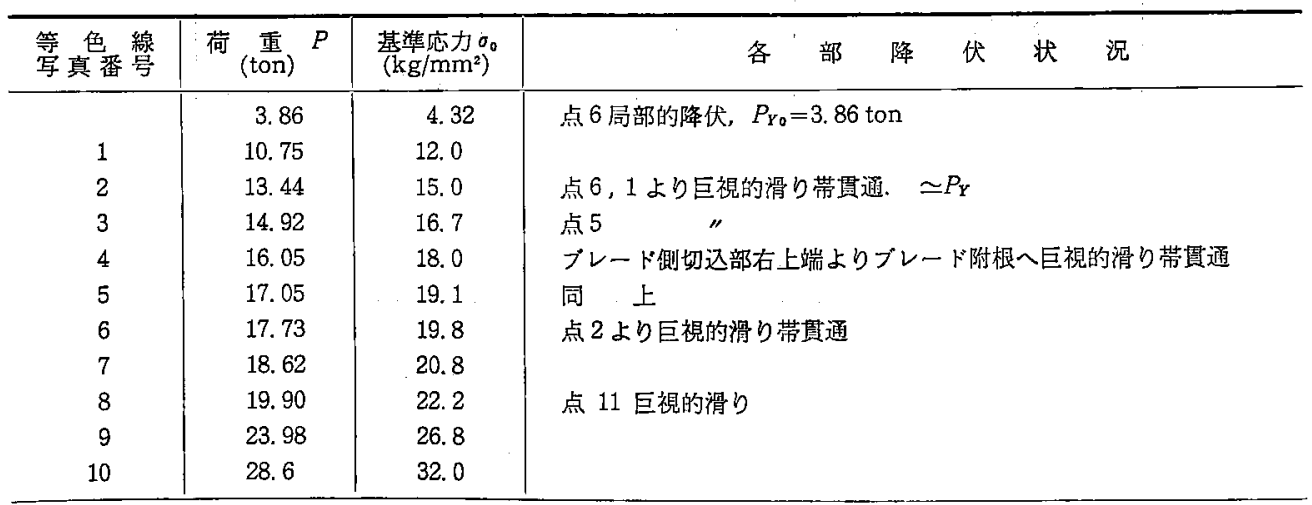




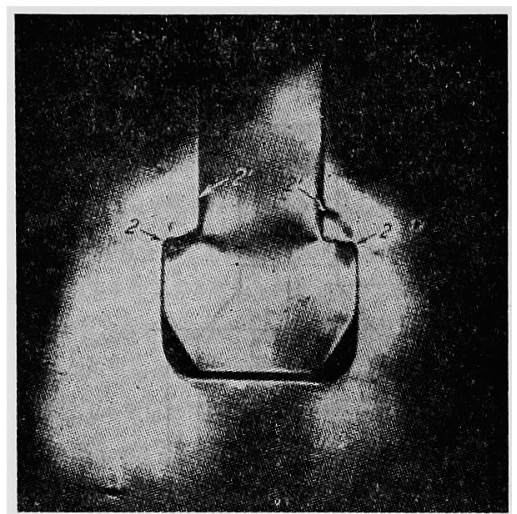

2 より $2^{\prime}$ に向けて急速に貫通する

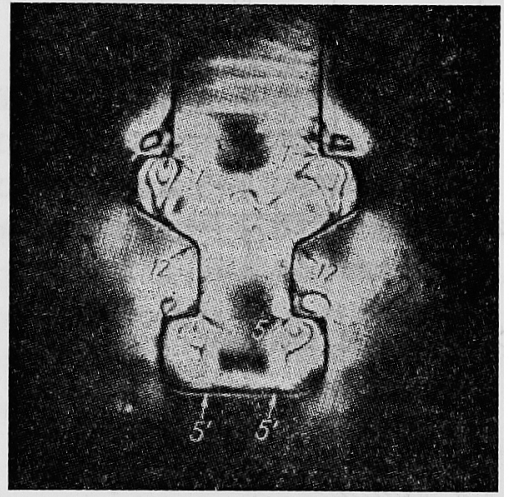

12 左 $\rightarrow 1$ 右, 12 右 $\rightarrow 1$ 左, $5 \rightarrow 5^{\prime \prime}$

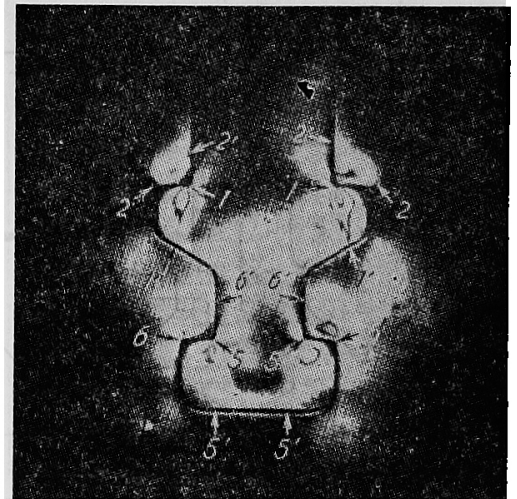

$1 \rightarrow 1^{\prime}, \quad 2 \rightarrow 2^{\prime}, \quad 6 \rightarrow 6^{\prime}, \quad 5 \rightarrow 5^{\prime}$

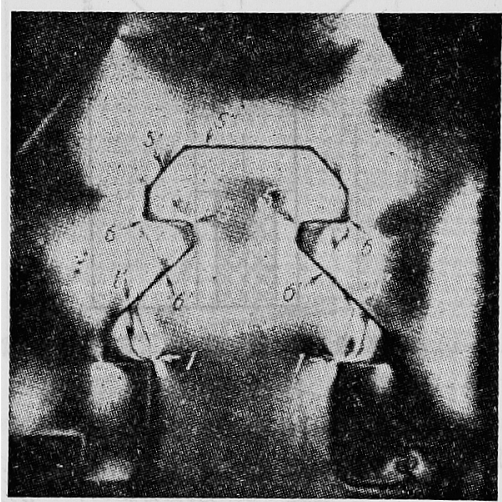

$6 \rightarrow 6^{\prime}, \quad 5 \rightarrow 5^{\prime}, \quad 5^{\prime \prime}, \quad 1 \rightarrow 1^{\prime}$

第 23 図 等色線図についての巨視的滑り帯の説明
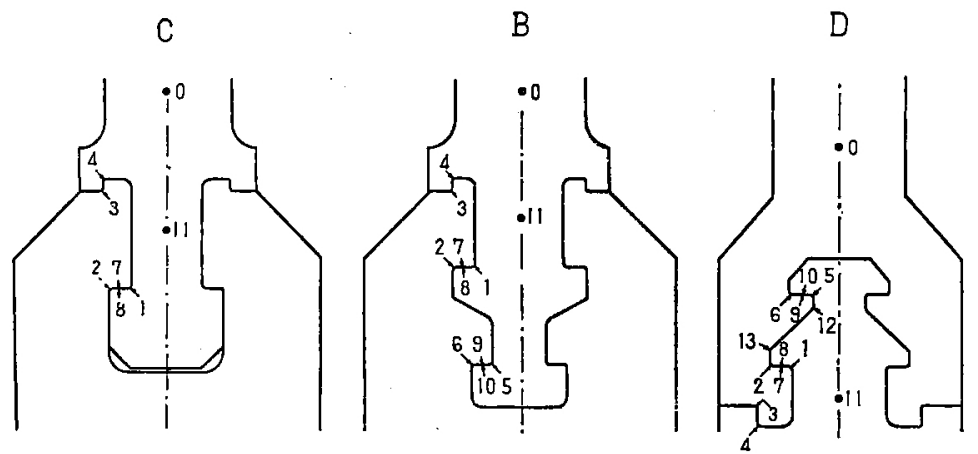

第 24 図 試験片の主要点の番号

第 5 表 タービン翼根部の弾性および洷性設計荷重

\begin{tabular}{cc|c|c|c}
\hline \multirow{2}{*}{ 科 } & \multirow{3}{*}{ 類 } & \multicolumn{3}{|c}{$\mathrm{SF}-50\left(\sigma_{Y}=32.8 \mathrm{~kg} / \mathrm{mm}^{2}\right)$} \\
\cline { 3 - 5 } & & $P_{Y_{0}}$ (ton) & $P_{Y}$ (ton) & $P_{Y} / P_{Y_{0}}$ \\
\hline $\mathrm{B}$ & 型 & 4.14 & 15.2 & 3.67 \\
$\mathrm{C}$ & 型 & 2.74 & 12.8 & 4.67 \\
$\mathrm{D}$ & 型 & 3.86 & 13.4 & 3.47 \\
\hline
\end{tabular}



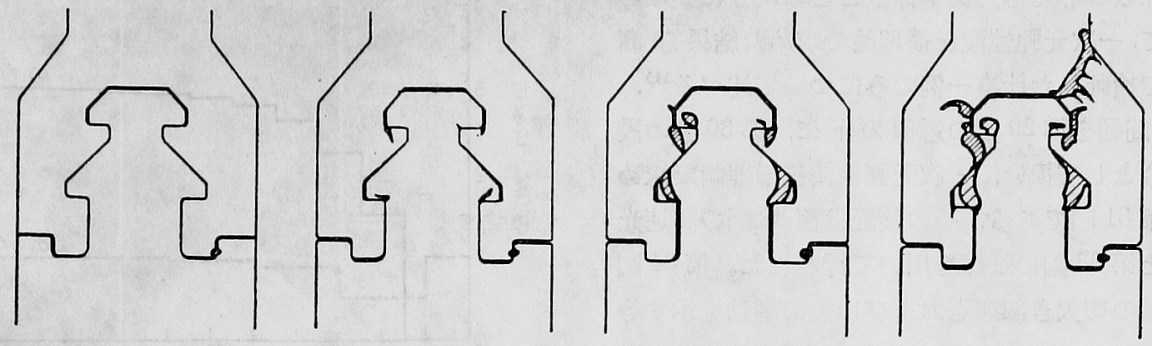

D-1. $P=10.75$ ton

D-2. $P=13.44$ ton

D-3. $P=14.92$ ton

D-4. $P=16.05$ ton
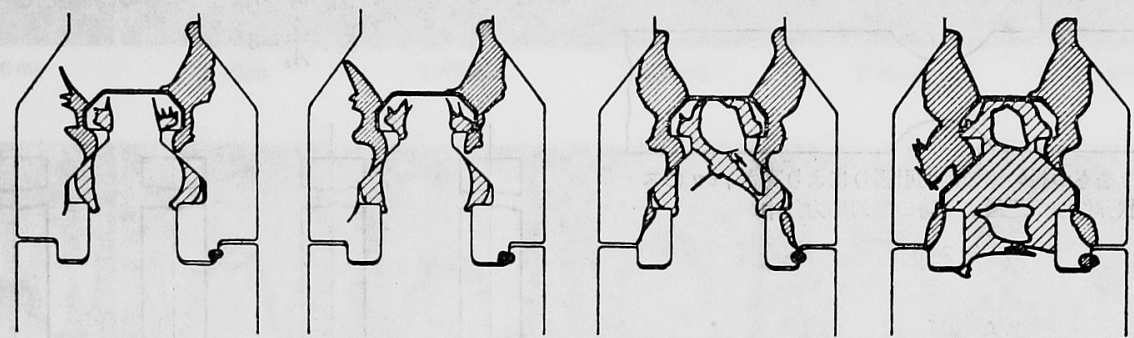

D-5. $P=17.05$ ton

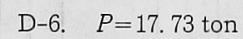

D-7. $P=18.62$ ton

D-8. $P=19.90$ ton
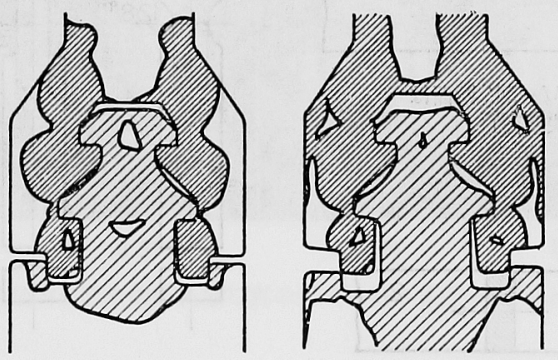

D-9. $P=23.98$ ton

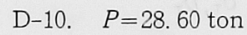

第 25 図 試験片 D の望性領域進展図

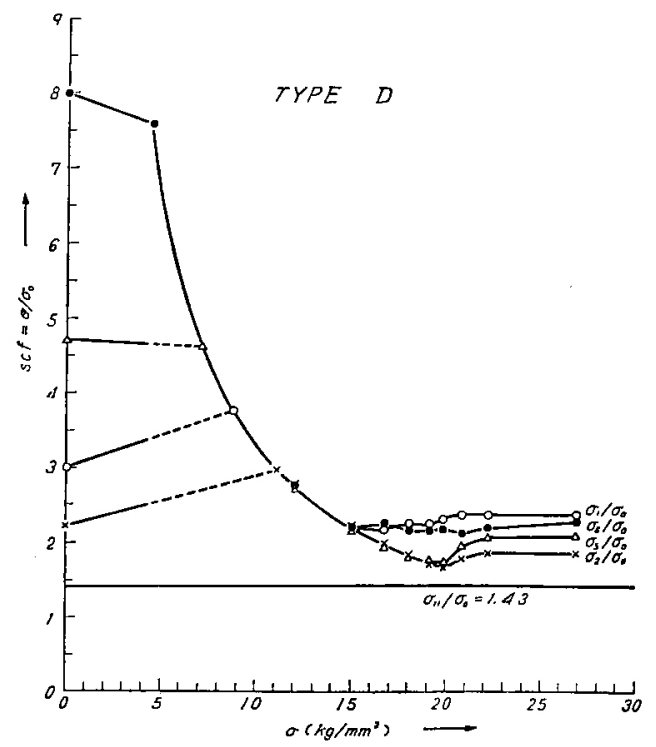

第 26 図 試驗片 D の引張りでの弾塑性応力偗ゆ係数

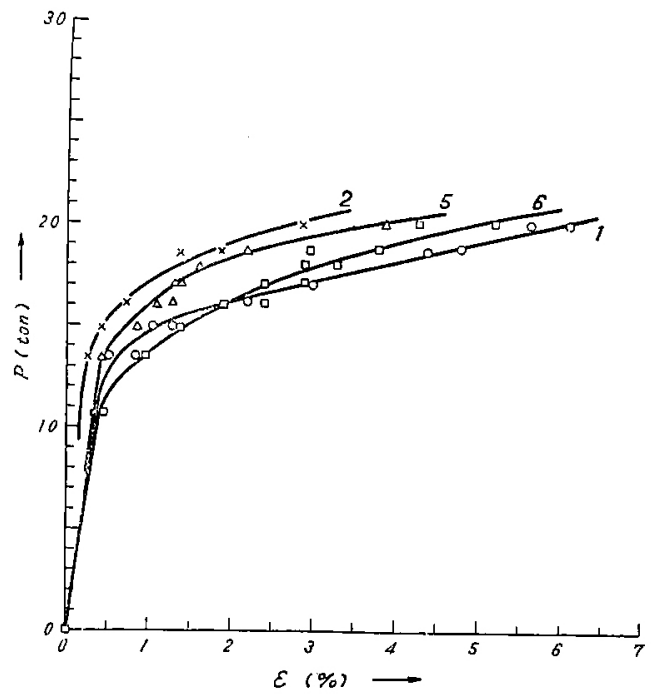

第 27 図試驗片Dの引張りでの荷重-主垔み線図 
応力集中保数が静的忘力集中係数之どのように異なる かについて,一次元弾性波伝播理論で求めた結果を, 高 速光弾性で検証した仕事一例のみについて述へる 第 28 図の問題を第 29 四の近似の下に，第 30 図の段 付棒の結合として报い，一次元弾性波伝播理論で求め た結果が第 31 図である. この検証は第 32 図の高速光 弾性装置之第 33 四の試片を用いて行われた. 第 34 図 は弾性波頭の切欠き部通過および以後の挙動を示す等

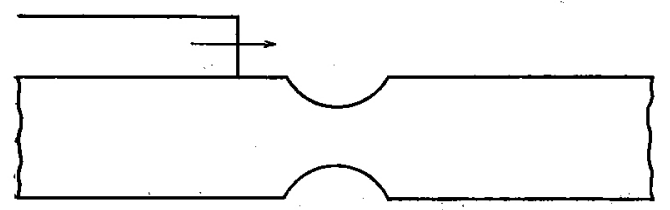

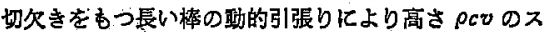
ップ状㗆性波が通過する時の動的応力集中 第 28 図

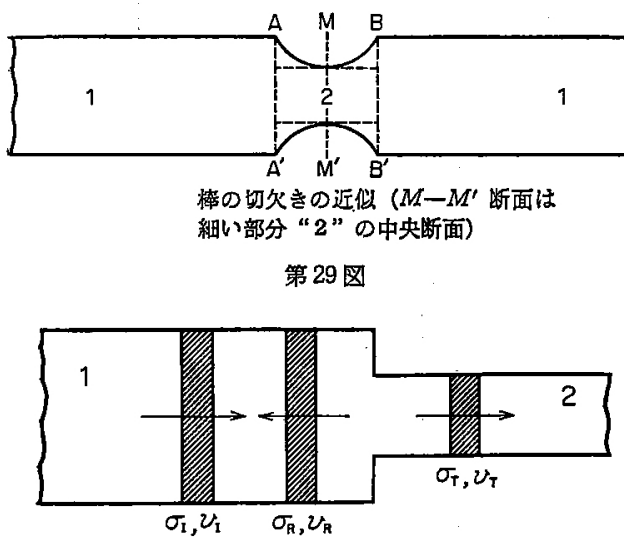

第 30 図 段付き弾性棒中の弾性波

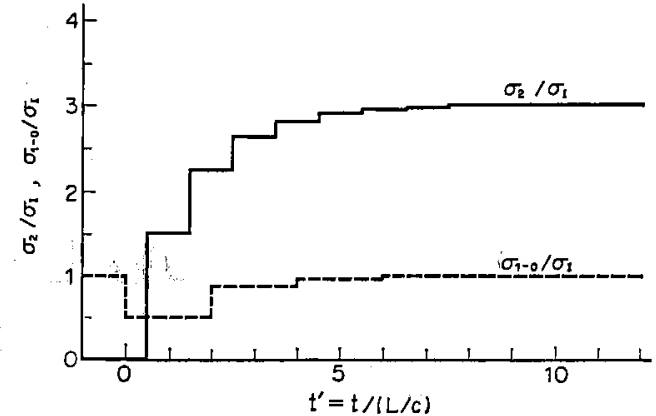

第 31 図 $\sigma_{2}$ および $\sigma_{1-0}$ の洔間変化

$$
\text { 例: } \frac{A_{1}}{A_{2}}=3
$$
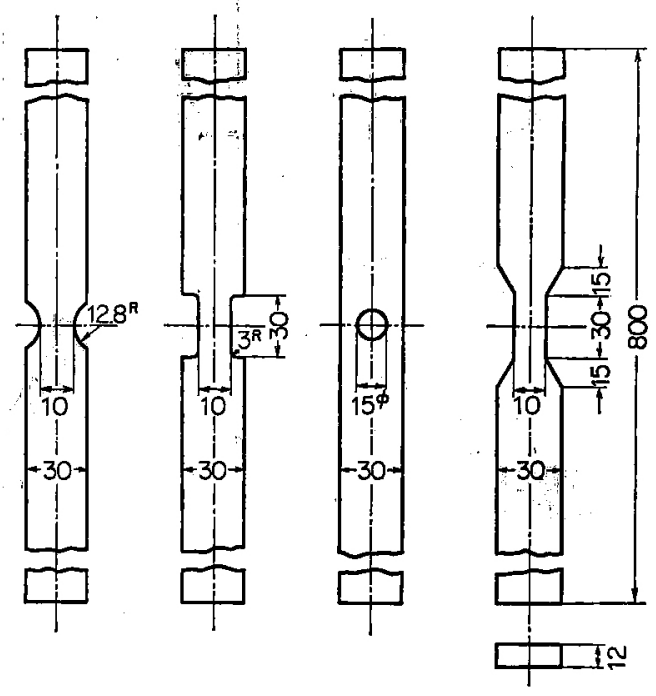

A
C D 第33図 ポリウレタン試験片寸度

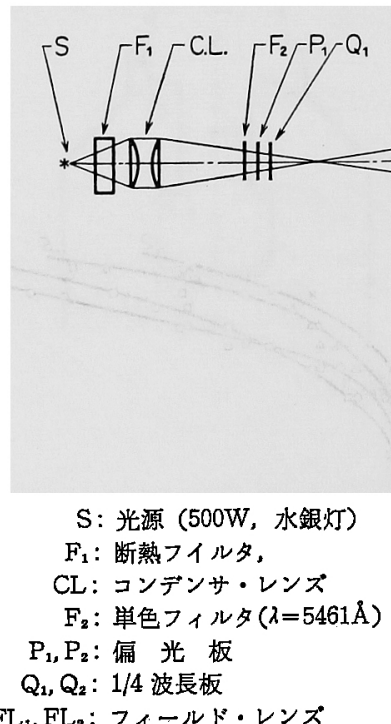

$\mathrm{T}$ : 試 臨

H. C. : 高速度カメラ

$\mathrm{M}$ : 電 磁 石

W: 重锤

M.S. : 磁気スイッチ

P.G.：タイミング・マーク用パルス・ジェネレータ CL : コントロール・ユニット 


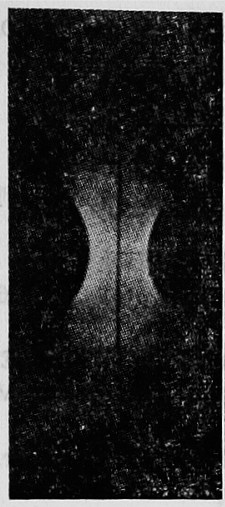

$0 \mathrm{~ms}$

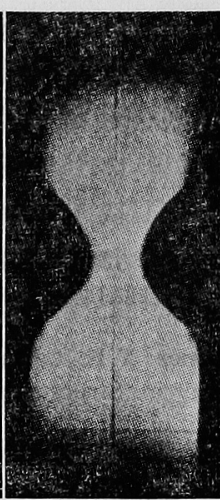

$1.25 \mathrm{~ms}$

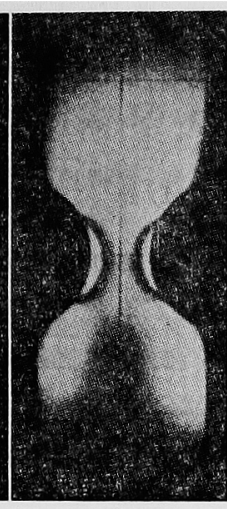

$1.47 \mathrm{~ms}$

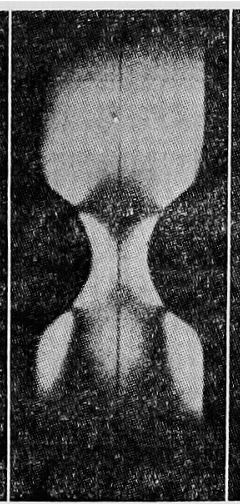

$1.70 \mathrm{~ms}$

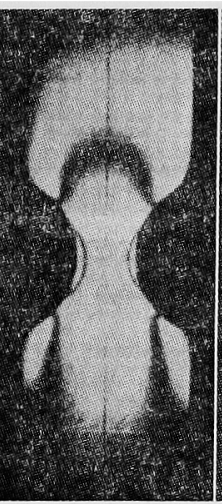

$1.93 \mathrm{~ms}$

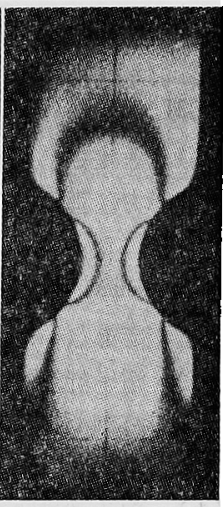

$2.15 \mathrm{~ms}$

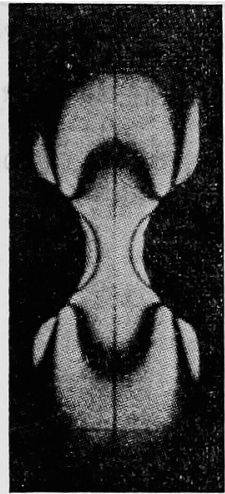

$2.72 \mathrm{~ms}$

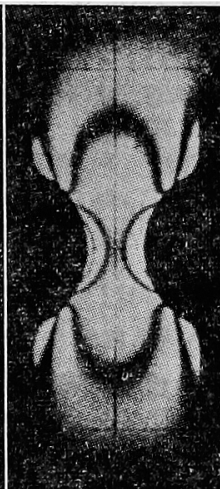

$3.28 \mathrm{~ms}$

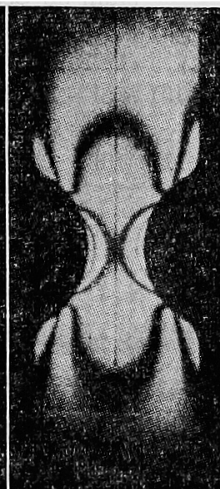

$5.55 \mathrm{~ms}$

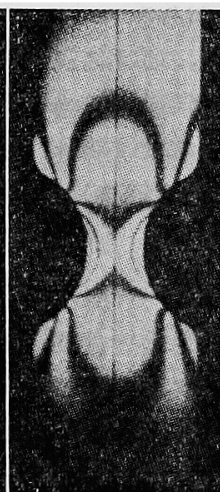

$7.91 \mathrm{~ms}$

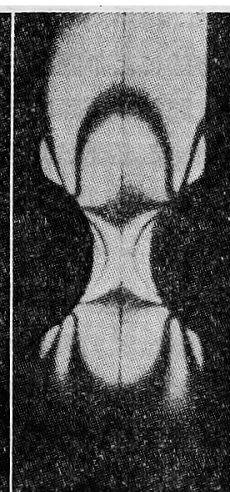

$10.1 \mathrm{~ms}$

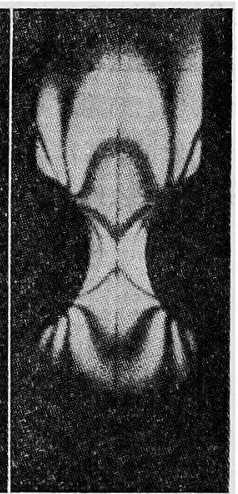

$14.6 \mathrm{~ms}$

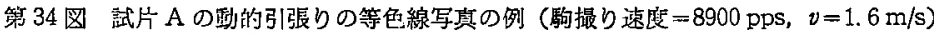

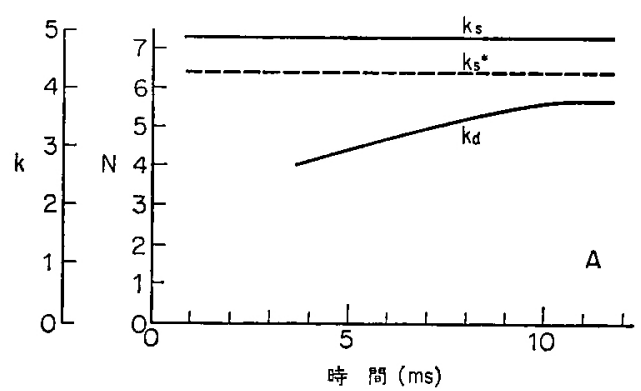

試片 $\mathrm{A} \odot K_{d}$ の变化

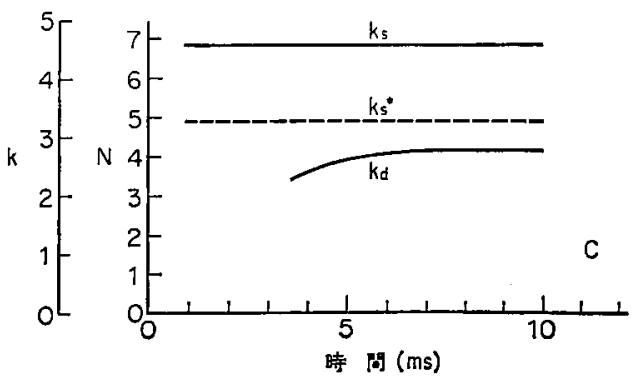

纾片 Cの $K_{d}$ の変化

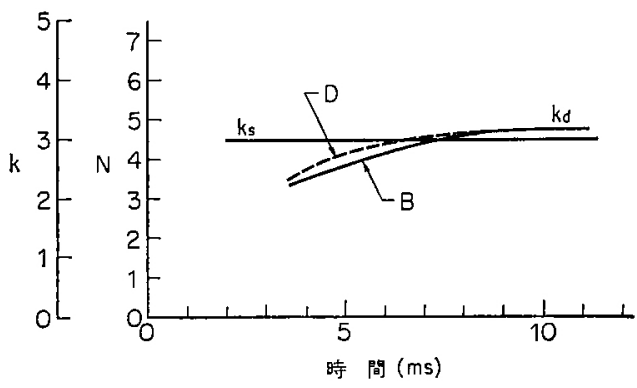

試片 B, D の $K_{d}$ の变化

第 35 図 $K_{d}$ の実測值 $\left(K_{s}^{*}\right.$ は陚片の変班を考虑した修 正值)

色線図で，第 35 娄 は件的応力集中係数 $K_{d}$ が静的応 力集中係数 $K_{s}$ に時問経過と之もに漸近する様子を示 す. 近年，ての分野の研究はますます拡充され，衙撃 工学分野で有力な武器となっている.

$$
\text { 8. ¿ め }
$$

以上を要するに, 実験力学および有限要素法の諸手 法は多彩を極め，その各分野は今後ともますます開発 
されるであろう．両者の注意点，特徴を概説してみれ ば,

FEM :

（1）仮定された構成方程式，負荷条件の範囲内で 応力，歪みを与える．基準の確定していない問 題，たとえば，破壊などは报い難い。

（2）FEM のみでは正解の上，下界をはさむとと ができない。

（3）電子計算機の容量，費用の点より，おのずか ら分割の限界があり，精度を限定する。

実験力学 :

（1）瓃物の構成方程式，真荷条件についての応 力，昰みを与える.

（2）個々の方法には，得手，不得手がある.

（3）精度は备々の方法により固有のあのがある.

ゆえに，結論として，問題の種類に応じ両者を適当 に使い分け，または併用する必要がある．特に光弾性 に限っていえば， 3 次元光弾性（特に非対称問題）,
高速光弾性，皮膜法実物弹望性（弾塑性一破壊の解 析）などが特に必要とされると思われる。

文献

1) 辻 二郎, 西田正萃, 河田幸三: 光弹性実験法（日刊工 業, 1965).

2）応力测定研究会：応力測定法 (朝倉, 1955).

3）川田雄一他：材料強度工学ハンドブック(朝倉, 1966).

4) 大井光四郎: 同上, 372.

5) O.C. Zrenkiewicz, Y.K. Cheung: The Finite Element Method in Structural \& Continuum Mechanics, McGraw-Hill (1967), など.

6) 河田幸三：機械学会誌，61 (1958)，1055，K. KAWATA； J. Sci. Res. Inst., 52 (1958), 17.

7) 河田幸三: 東大航研集報，1-5 (1959)，320.

8) K. Kawata, Y. Nakamura: Proc. 9 th Int. Symposium on Space Tech. \& Sci. (Tokyo, 1971), 225.

9) 河田幸三，黑河邦彦：第 2 回宇宙航空林料シンポジゥム (1972)，1

10）河田幸三, 黑河邦彦, 橋本彰三：第 1 回光弾性シンポシ ウム論文集 (1972)，191.

11）河田幸三，攜本彰三: 東大宇研報告, 8-2 (B) (1972), 377. 